\title{
Synthesis and Properties
}

\author{
Karine De Oliveira Vigier and François Jérôme
}

Université de Poitiers, B1, ENSIP, IC2MP UMR CNRS 7285, 1 rue Marcel Doré, TSA 41105, 86073, Poitiers Cédex, France

\subsection{Introduction}

At the beginning of this century, deep eutectic solvents (DESs) appeared as a new class of green solvents [1] and they are considered as a new class of ionic liquids (ILs) due to their similar characteristics and properties. However, they are two different types of solvents. An ionic liquid is an association of a cation and an anion. In contrast, DES is a combination of two or more solids that form, through hydrogen bond formation, a eutectic liquid mixture at a temperature lower than the melting point of each compound that is part of the DES [2]. The intersection of the eutectic temperature and the eutectic composition gives the eutectic point ( $\mathrm{E}$ in Figure 1.1). $\mathrm{E}$ is the point where the eutectic mixture is a unique composition of two or more nonmiscible phases of solid components that after association form a liquid at a defined temperature.

The interest in DESs increased considerably at industrial or academic level as shown by the number of publications dedicated to DESs. This is due to their great convenience of synthesis, their low production costs by using safe components, and their unusual reactivities near the eutectic point [3]. Moreover, the possibility to tune their properties makes them ideal candidates to be used for a wide range of applications. They are usually composed of Lewis or Brønsted acids and bases, which can contain a variety of anionic and/or cationic species. One of the components most used to produce DESs is choline chloride $(\mathrm{ChCl})$. It is a cheap, biodegradable and nontoxic salt that can be extracted from biomass or produced from fossil carbon. Some of these mixtures present rather a glass transition temperature point than a eutectic point, and are therefore also called low-melting mixtures [4] or low-transition-temperature mixtures [5]. Just like ionic liquids, DESs often have a melting point close to RT, and exhibit low volatility and high thermal stability. However, DESs are biodegradable, cheap, and very easy to prepare. This chapter aims at a general presentation of the synthesis of these solvents and their physicochemical properties. 


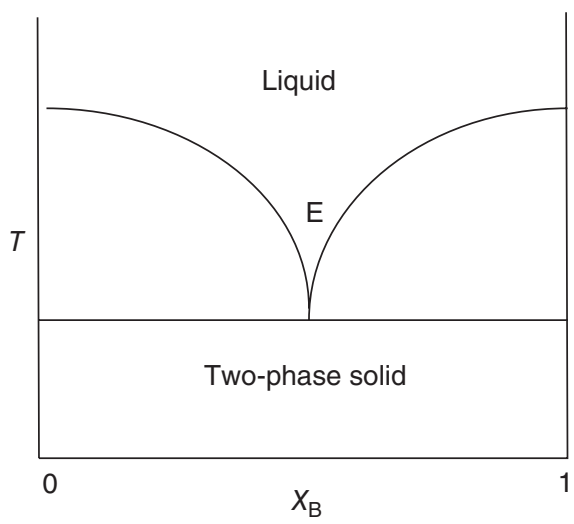

Figure 1.1 Representation of a eutectic point.

\subsection{Synthesis}

Generally, DESs can be prepared from two or more cheap and safe components through hydrogen bond interactions between the hydrogen bond donor (HBD) and the hydrogen bond acceptor (HBA) [6]. Practically, they are prepared by adding directly an appropriate amount of $\mathrm{HBD}$ and salt into a flask. After heating and stirring, a colorless liquid is formed. Obviously, the molar ratio corresponding to the eutectic point is variable in composition and also in temperature according to the nature of each component. The synthesis procedure of DESs is very simple and produces no waste products. Therefore, the synthesis of DESs is green and environmentally benign because their reaction has zero emissions, zero $E$-factor value. Moreover, the atom economy of the final formation of the DES is $100 \%$, because all initial components are included in the final mixture. All of these factors make their ecological footprint minimal [7]. At an economic level, DESs are inexpensive and approximately 10-fold less expensive than the components of ILs [8].

The number of DESs that can be synthesized from the available chemicals has no limitation owing to the large number of quaternary ammonium, phosphonium, or sulfonium salts and HBDs that can be used to synthesize the DESs (Figure 1.2). Therefore, it is almost impossible to study all the combinations.

DESs are composed of large, nonsymmetric ions with low lattice energy and thus low melting points owing to the charge delocalization occurring through hydrogen bonding between, for example, a halide ion and the hydrogen donor moiety. Typical DESs are composed of choline chloride, natural amino acids such as Lewis/Brønsted bases or urea, natural carboxylic acids, or polyalcohols such as Brønsted acids. One can note that they come from renewable sources. For example, $\mathrm{ChCl}$ is an additive in chicken food for accelerating their growth, and is simply produced from trimethylamine, hydrochloric acid, and ethylene oxide in a continuous, single-stream process. The toxicity of DESs is nonexistent or very low [9] and their biodegradability is extraordinarily high [10]. Moreover, the high solubility of DESs in water allows the separation of organic products that will precipitate 


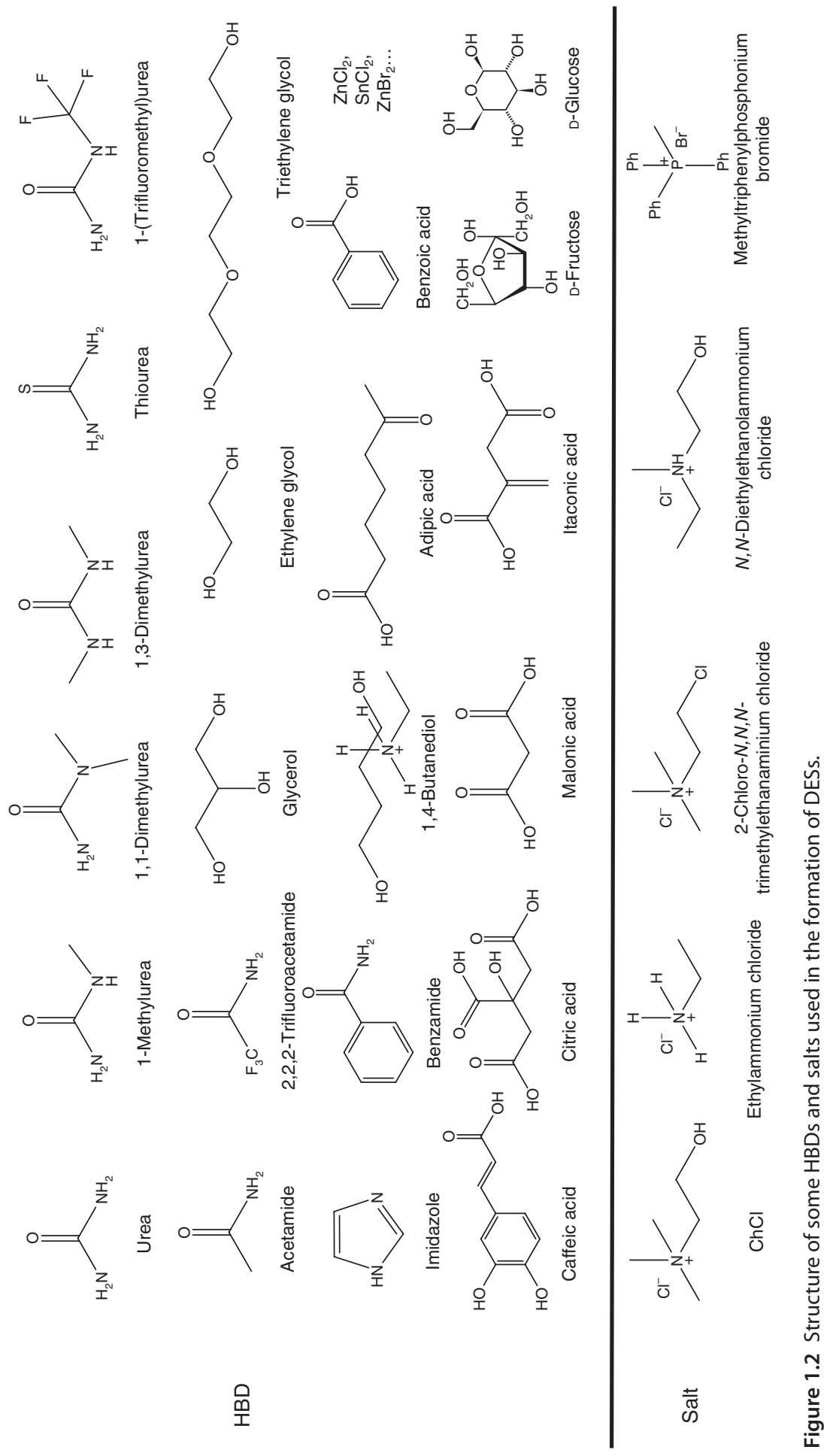


Table 1.1 The fourth type of DESs.

\begin{tabular}{llll}
\hline Types & General formula & Terms & Example \\
\hline I & $\mathrm{Cat}^{+} \mathrm{X}^{-}+z \mathrm{MCl}_{x}$ & $\mathrm{M}=\mathrm{Zn}, \mathrm{In}, \mathrm{Sn}, \mathrm{Al}, \mathrm{Fe}$ & $\mathrm{ChCl}+\mathrm{ZnCl}_{2}$ \\
II & $\mathrm{Cat}^{+} \mathrm{X}^{-}+z \mathrm{MCl}_{x}$ & $\mathrm{M}=\mathrm{Cr}, \mathrm{Ni}, \mathrm{Cu}, \mathrm{Fe}, \mathrm{Co}$ & $\mathrm{ChCl}+\mathrm{CoCl}_{2} \cdot 6 \mathrm{H}_{2} \mathrm{O}$ \\
III & $\mathrm{Cat}^{+} \mathrm{X}^{-}+z \mathrm{RZ}$ & $\mathrm{Z}=\mathrm{OH}, \mathrm{COOH}, \mathrm{CONH} H_{2}$ & $\mathrm{ChCl}+$ urea \\
IV & $\mathrm{MCl}_{x}+z \mathrm{RZ}$ & $\mathrm{M}=\mathrm{Zn}, \mathrm{Al}$ and $\mathrm{Z}=\mathrm{OH}, \mathrm{CONH}_{2}$ & $\mathrm{ZnCl}_{2}+$ urea \\
\hline
\end{tabular}

or appear as a water-insoluble layer with the addition of water that dissolves the DES, avoiding the typical organic solvent extraction at the end of the reaction. DES can be recycled with the evaporation of water from the aqueous layer. In 2007, Abbott et al. provided the general formula $R_{1} R_{2} R_{3} R_{4} N^{+} X^{-} Y^{-}$[11] for DESs. DESs are classified depending on the nature of the complexing agent used $[2,12]$ (Table 1.1). Four types of DESs exist. DESs of Type I are composed of quaternary ammonium salt and metal chloride and can be considered as analogous to metal halide/imidazolium salt systems. Examples of Type I eutectics include chloroaluminate/imidazolium salt melts and DESs formed with imidazolium salts and various metal halides including $\mathrm{FeCl}_{2}, \mathrm{AgCl}, \mathrm{CuCl}, \mathrm{LiCl}, \mathrm{CdCl}_{2}, \mathrm{CuCl}_{2}$, $\mathrm{SnCl}_{2}, \mathrm{ZnCl}_{2}, \mathrm{LaCl}_{3}, \mathrm{YCl}_{3}$, and $\mathrm{SnCl}_{4}$. DESs of Type II are composed of quaternary ammonium salt and metal chloride hydrate. The relatively low cost of many hydrated metal salts coupled with their inherent air/moisture insensitivity makes their use in industrial processes viable. DESs of Type III are composed of quaternary ammonium salt and HBD. In Type III, choline chloride and HBDs have been widely used for many applications such as metal extraction and organic synthesis $[2,6,13]$. Type IV DESs are composed of metal chloride and HBD.

These liquids are simple to prepare and relatively unreactive with water; many are biodegradable and have relatively low cost. The wide range of HBDs available indicates that this class of DESs is particularly adaptable. The physical properties of the liquid are dependent upon the HBD and can be easily tailored for specific applications.

\subsection{Properties}

Owing to their physicochemical and thermal properties (density, viscosity, surface tension, conductivity, freezing temperature $\left[T_{\mathrm{f}}\right]$, miscibility, and polarity), which can be easily tuned by altering the components and their ratios, DESs have a big potential as solvents [2,6]. Moreover, a high number of DESs can be obtained, making this new type of solvents even more designable.

\subsubsection{Freezing Point $\left(T_{\mathrm{f}}\right)$}

As mentioned previously, DESs are formed by mixing two solids capable of generating a new liquid phase via hydrogen bonds formation. This liquid phase is characterized by a lower freezing point than that of the individual constituents. 
This decrease of the freezing point comes from an interaction between HBD and the salt. Table 1.2 reports the freezing points of various DESs described in the literature. Although for all DESs reported in the literature the freezing point is lower than $150^{\circ} \mathrm{C}$, it should be pointed out that the number of DESs that are liquid at room temperature (RT) is still quite limited. Among DESs that are liquid at room temperature, we can cite the combination of glycerol or urea with $\mathrm{ChCl}$, presumably due to their stronger ability to form hydrogen bond interactions with $\mathrm{ChCl}$. It means that depending on the halide salt, the choice of HBDs is a critical point in the formation of a DES with a low freezing point. For instance, with $\mathrm{ChCl}$ as a salt, HBDs such as carboxylic acids (levulinic acid, malonic acid, phenylpropionic acid, etc.) or sugar-derived polyols (e.g. xylitol, D-isosorbide, and D-sorbitol) lead to room temperature liquid DESs. In the same way, for a defined HBD the nature of the halide salts (e.g. ammonium or phosphonium salts) also affects the freezing points of the corresponding DESs. For example, when urea is selected as HBD and mixed with different salts in a molar ratio of $2: 1$ (urea:salt), the obtained DESs exhibit very different freezing points, from -38 to $113^{\circ} \mathrm{C}$ (Table 1.2). For a similar salt, the nature of the anion is also of importance for the freezing point of DESs. For example, the freezing point of a choline-salt-derived DES in combination with urea decreases in the order $\mathrm{F}^{-}>\mathrm{NO}_{3}{ }^{-}>\mathrm{Cl}^{-}>\mathrm{BF}_{4}{ }^{-}$. Another parameter that can affect the freezing point of DESs is the salt/HBD molar ratio. Thus, for ethylene glycol and $N, N$-diethylethanolammonium chloride, the freezing point of the DES obtained increases with increase of the salt/ HBD molar ratio from $1: 2$ to $1: 4$ (Table 1.2).

Taking into account the different types of eutectic liquids, we can highlight some trend. Globally, the Type I eutectics that are composed of interactions between different anhydrous metal halides $\left(\mathrm{ZnCl}_{2}, \mathrm{ZnBr}_{2}, \mathrm{SnCl}_{2}\right.$, etc.) and the halide anion from quaternary ammonium salt $(\mathrm{ChCl}, 2$-acetoxy- $N, N, N$-trimethylethanaminium chloride, 2-acetoxy- $N, N, N$-trimethylethanaminium chloride, $N$-(2hydroxyethyl)-N,N-dimethylanilinium chloride) will all produce similar halometallate species with similar enthalpies of formation. This suggests that $\Delta T_{\mathrm{f}}$ values should be between 200 and $300^{\circ} \mathrm{C}$. It has been observed that to produce a eutectic at ambient temperature the metal halide generally needs to have a melting point of approximately $300^{\circ} \mathrm{C}$ or less.

That is the reason why metal halides such as $\mathrm{FeCl}_{3}$ (m.p. $=308^{\circ} \mathrm{C}$ ) [35], $\mathrm{SnCl}_{2}$ (m.p. $=247^{\circ} \mathrm{C}$ ) [36], and $\mathrm{ZnCl}_{2}$ (m.p. $=290^{\circ} \mathrm{C}$ ) [36] produce ambient temperature eutectic liquids.

Type II eutectics are composed of hydrated metal halides and a HBD. Hydration of the metal salt leads to a lower melting point than that of the corresponding anhydrous salt due to decrease in the lattice energy. The freezing points of Type III DESs depend on the hydrogen bond interaction and the salt/HBD molar ratio. Type IV eutectic mixtures present a freezing point below $10^{\circ} \mathrm{C}$ in all cases (Table 1.2).

\subsubsection{Density}

Density is a thermophysical property of interest (Table 1.3). The density of most of the DESs is between 1.0 and $1.35 \mathrm{~g} / \mathrm{cm}^{3}$ at $298.15 \mathrm{~K}$, which is higher than the 


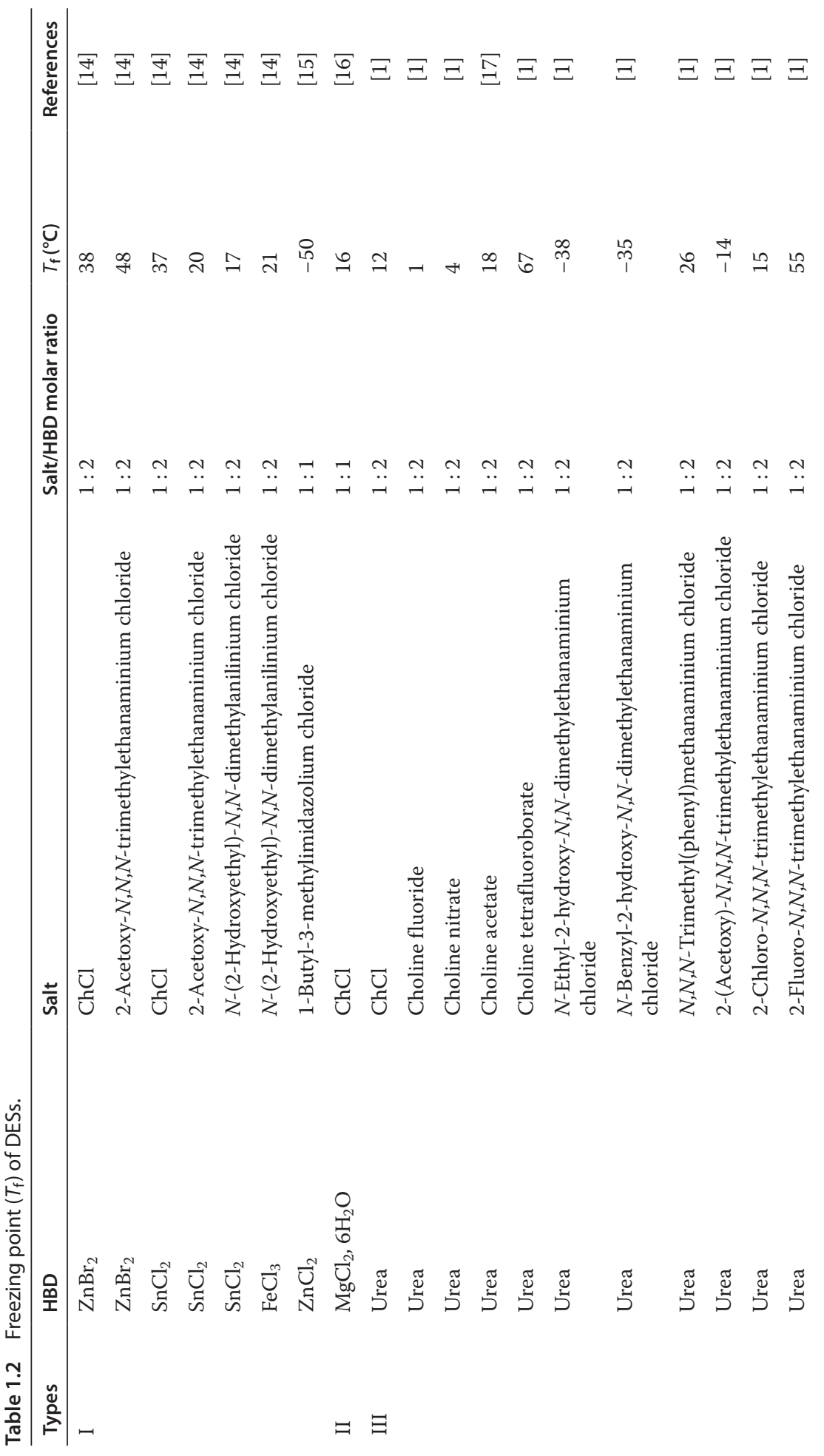




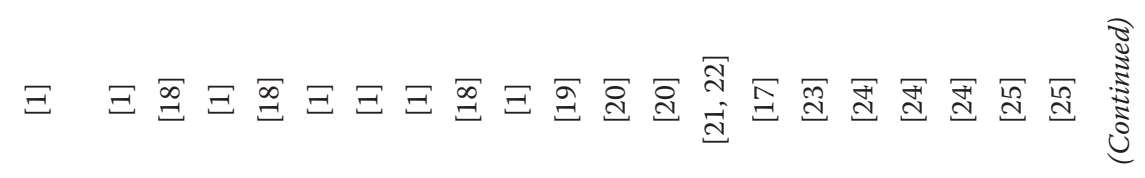

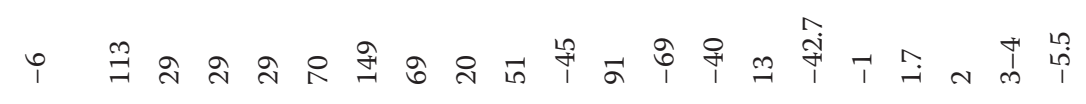

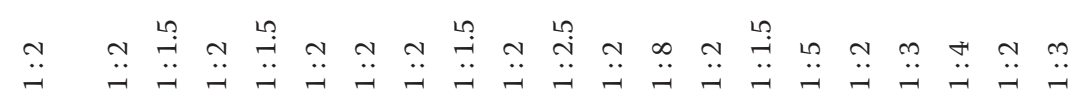
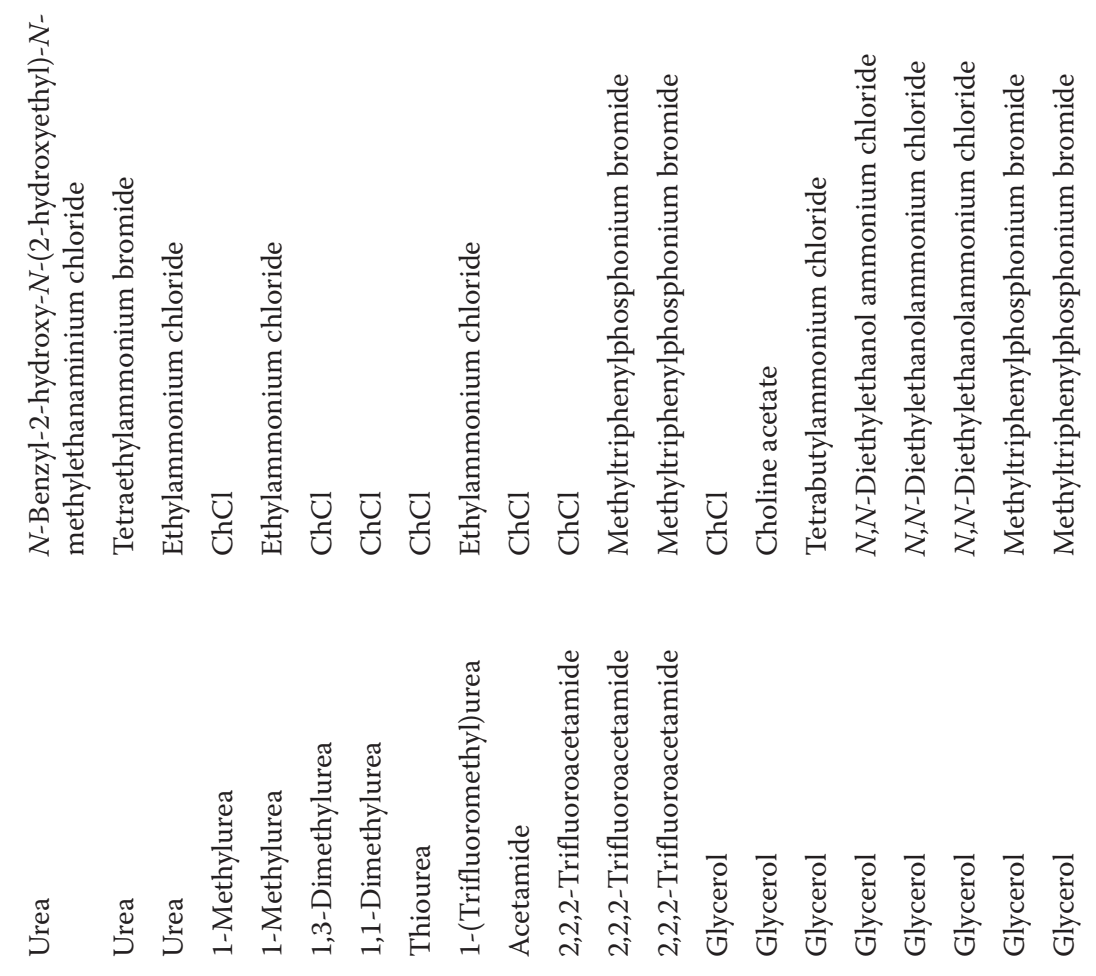


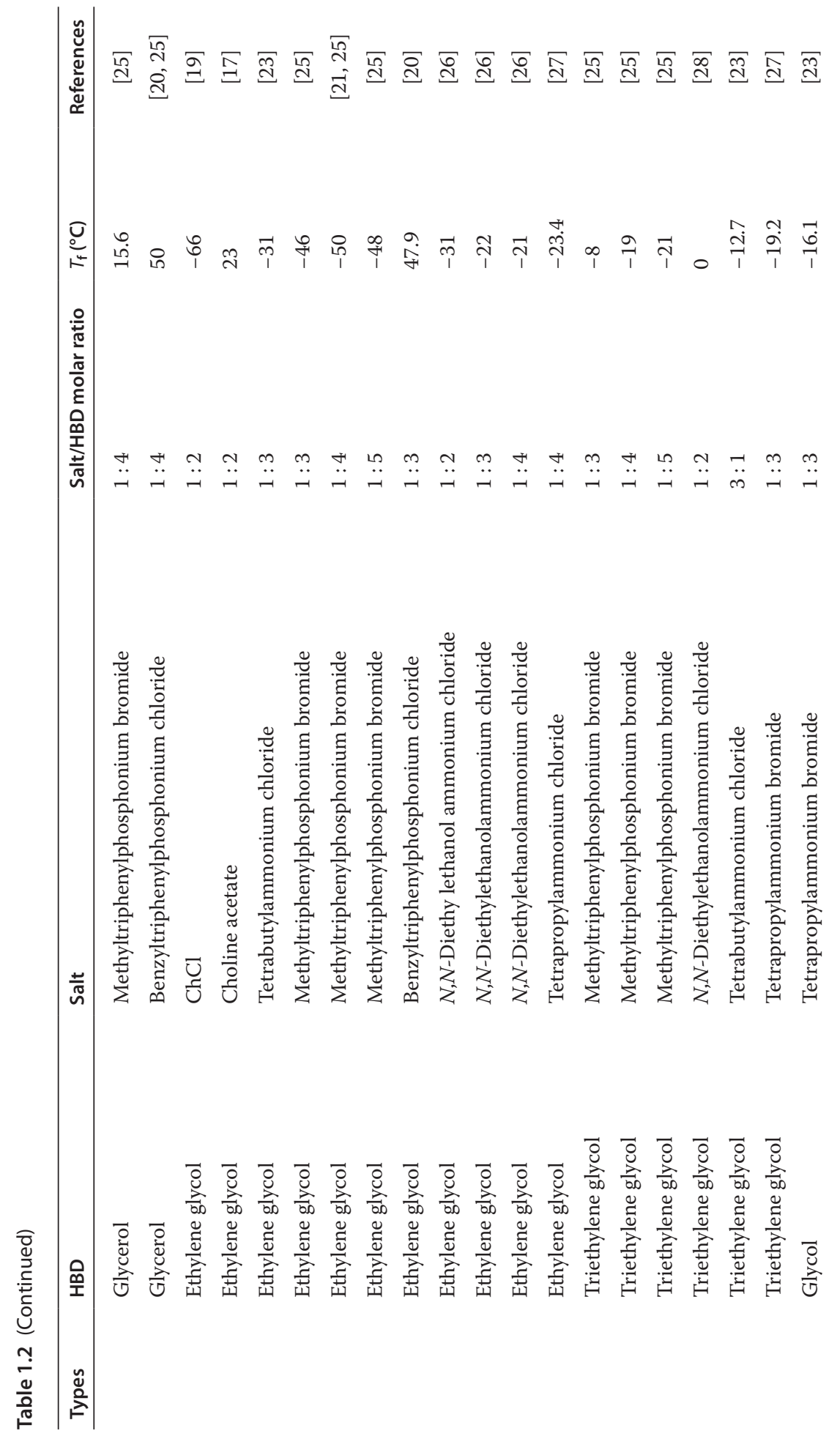




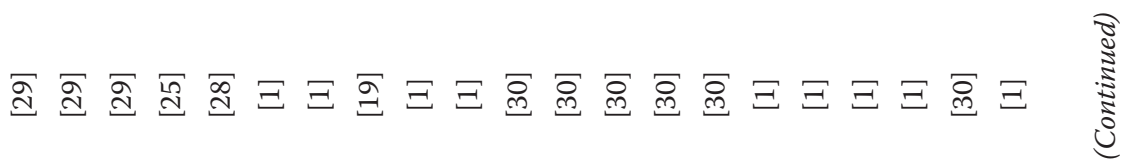

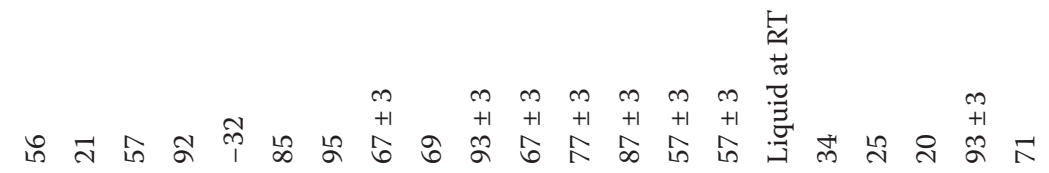

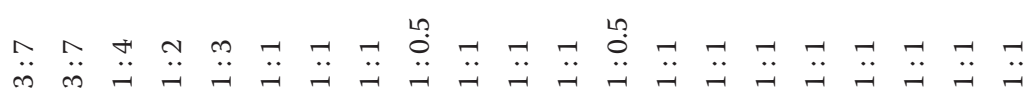
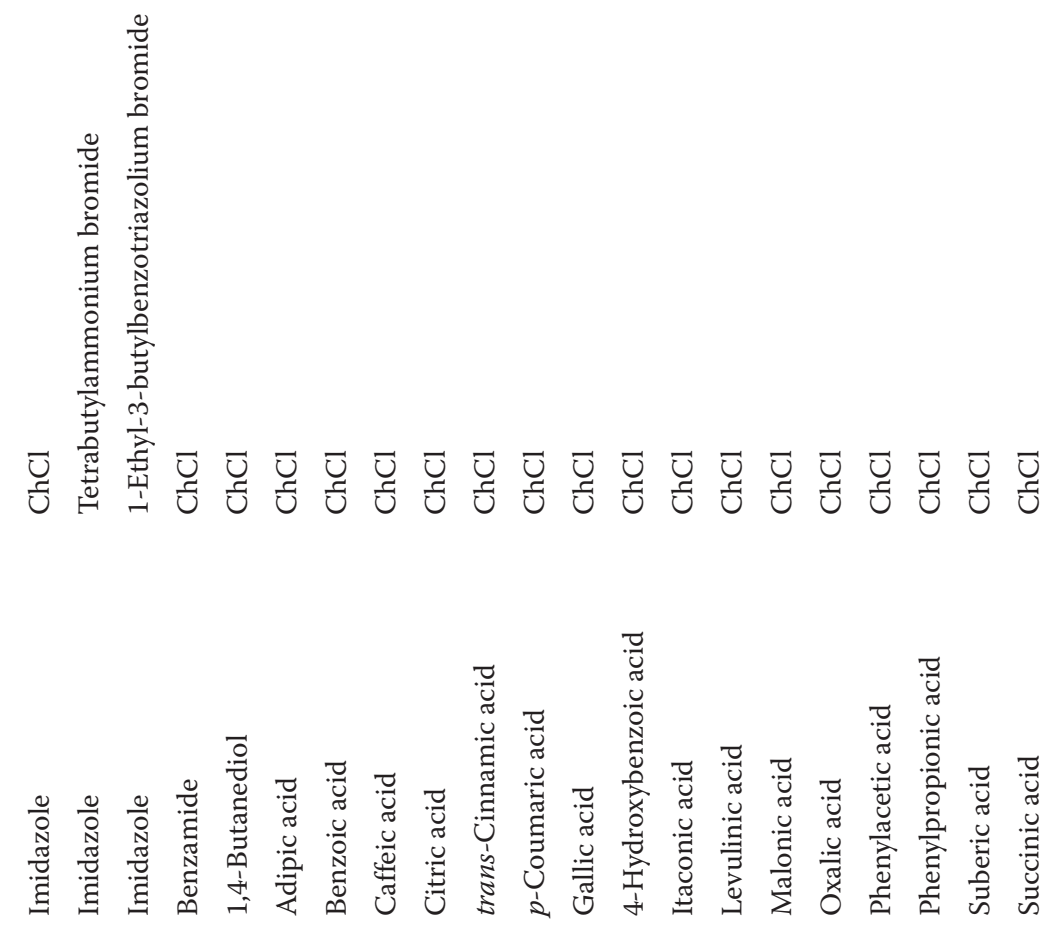


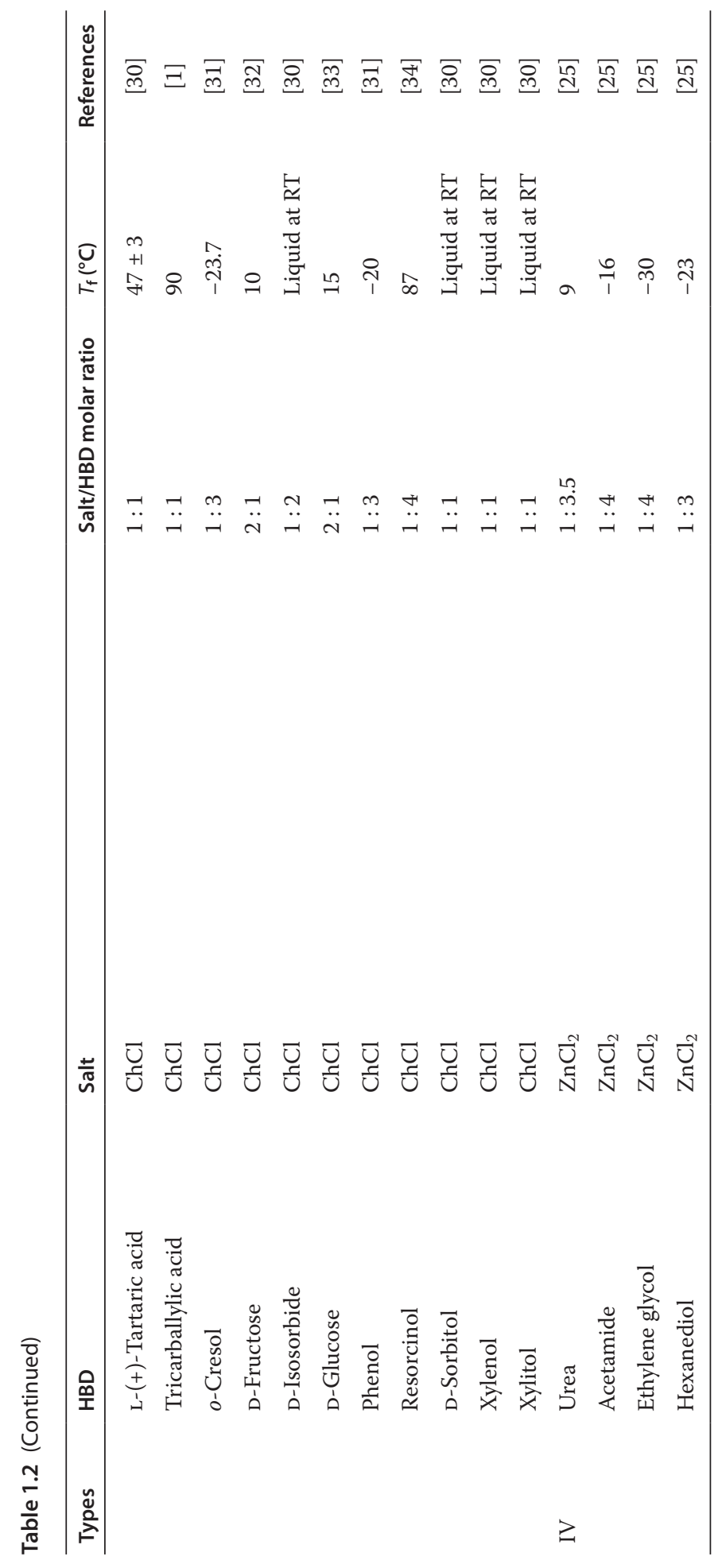


density of water. However, DESs containing metallic salts such as $\mathrm{ZnCl}_{2}$ have densities in the $1.3-1.6 \mathrm{~g} / \mathrm{cm}^{3}$ range [16]. This difference in density may be explained by the hole theory since DESs are composed of holes or empty vacancies. When $\mathrm{ZnCl}_{2}$ was mixed with urea, for instance, the average hole radius was decreased, resulting in a slight increase in the DES density as compared to that of neat urea [11]. The density of DES and its temperature variation is correlated to the molecular characteristics of the HBD. The density of DESs composed with a HBD that contains hydroxyl group increases with their number (higher values for glycerol than for ethylene glycol) and decreases with the introduction of aromatic groups (lower values for phenol and $o$-cresol, Table 1.3). One can note that $\mathrm{ChCl} /$ phenol and $\mathrm{ChCl} / o$-cresol are the two DESs with lower densities among all the ones studied $\left(1.092 \mathrm{~g} / \mathrm{cm}^{3}\right.$ for phenol and $1.07 \mathrm{~g} / \mathrm{cm}^{3}$ for $o$-cresol). Another parameter that can affect the density of DES is the chain length for the case of diacid DES. An increase in the chain length led to a decrease in the density. For example, for a C2-diacid such as oxalic acid, the density is $1.259 \mathrm{~g} / \mathrm{cm}^{3}$, whereas for C5-diacid such as glutaric acid, it is $1.188 \mathrm{~g} / \mathrm{cm}^{3}$ at $25^{\circ} \mathrm{C}$ [37]. It was reported that for two C5-diacids such as levulinic acid and glutaric acid, the density was higher for levulinic acid due to the higher amount of acid in the composition of DES than in the DES formed with glutaric acid. Indeed, a salt/HBD ratio of $1: 2$ is required to obtain a DES from levulinic acid and $\mathrm{ChCl}$, whereas this ratio is $1: 1$ for glutaric acid-based DES. If a comparison is made with a similar chain length for acid compound, we can note that the presence of a diacid group increases the density as observed for oxalic and glycolic acids (respectively 1.259 and $1.195 \mathrm{~g} / \mathrm{cm}^{3}$ ). The density of DESs is correlated to steric effects (the salt:HBD molar ratio) and the strength and extension of ions - HBD [26]. Based on the large number of possible salt-HBD combinations, it is required to develop predictive models to determine the relationships between the structure and property of DESs. The group of Mjalli [26, 38] has carried out a systematic research effort to test the ability of several theoretical approaches for the prediction of the density of DESs at different temperatures [39]. It was shown that the average of absolute relative percentage errors for all the DESs tested was $1.9 \%$.

\subsubsection{Viscosity}

The viscosity of DESs is an important parameter that should be studied. It is known that the viscosity of DESs is often high $(>100 \mathrm{cP})$ as reported in Table 1.4. However, DESs formed by the association of $\mathrm{ChCl}$ with ethylene glycol or 1,4butanediol, or $o$-cresol or phenol, for instance, possess a viscosity lower than $100 \mathrm{cP}$ at $20-30^{\circ} \mathrm{C}$. In general, viscosities of eutectic mixtures are mainly affected by the chemical nature of the DES components (nature of the salts and HBDs, salt/HBD molar ratio, etc.). For example, the viscosity of ChCl-based DESs is closely dependent on the nature of the HBD. Thus, $\mathrm{ChCl} /$ ethylene glycol $(1: 4)$ DES exhibits the lowest viscosity $\left(19 \mathrm{cP}\right.$ at $\left.20^{\circ} \mathrm{C}\right)$ whereas the viscosity of $\mathrm{ChCl} /$ $\mathrm{ZnCl}_{2}$ is very high $\left(8500 \mathrm{cP}\right.$ at $\left.25^{\circ} \mathrm{C}\right)$. As well, derived sugars (e.g. xylitol, sorbitol) or carboxylic acids (e.g. malonic acid) as HBDs led to DESs exhibiting high viscosities (e.g. $12730 \mathrm{cP}$ at $20^{\circ} \mathrm{C}$ for $\mathrm{ChCl} /$ sorbitol and $1124 \mathrm{cP}$ at $25^{\circ} \mathrm{C}$ for $\mathrm{ChCl} /$ malonic acid). This can be ascribed to intermolecular hydrogen bond network. 
Table 1.3 Densities of selected DESs at $25^{\circ} \mathrm{C}$.

\begin{tabular}{|c|c|c|c|c|c|}
\hline Types & HBD & Salt & $\begin{array}{l}\text { Salt/ } \\
\text { HBD } \\
\text { molar } \\
\text { ratio }\end{array}$ & $\begin{array}{l}\rho \\
\left(\mathrm{g} / \mathrm{cm}^{3}\right)\end{array}$ & References \\
\hline I & $\mathrm{AlCl}_{3}$ & $\begin{array}{l}\text { 1-n-Butyl-3-methylimidazolium } \\
\text { chloride }\end{array}$ & & 1.33 & \\
\hline \multirow[t]{22}{*}{ III } & Urea & $\mathrm{ChCl}$ & $1: 2$ & 1.25 & {$[18,19]$} \\
\hline & Urea & Choline acetate & $1: 2$ & 1.206 & {$[18]$} \\
\hline & Urea & Ethylammonium chloride & $1: 1.5$ & 1.140 & {$[18]$} \\
\hline & $\begin{array}{l}\text { 1-(Trifluoromethyl) } \\
\text { urea }\end{array}$ & Ethylammonium chloride & $1: 1.5$ & 1.273 & {$[18]$} \\
\hline & $\begin{array}{l}\text { 1-(Trifluoromethyl) } \\
\text { urea }\end{array}$ & $\mathrm{ChCl}$ & $1: 1.5$ & 1.324 & {$[18]$} \\
\hline & Acetamide & Ethylammonium chloride & $1: 1.5$ & 1.041 & {$[18]$} \\
\hline & $\begin{array}{l}2,2,2- \\
\text { Trifluoroacetamide }\end{array}$ & $\mathrm{ChCl}$ & $1: 2.5$ & 1.342 & [1] \\
\hline & $\begin{array}{l}2,2,2- \\
\text { Trifluoroacetamide }\end{array}$ & $\begin{array}{l}\text { Methyltriphenylphosphonium } \\
\text { bromide }\end{array}$ & $1: 8$ & 1.39 & {$[40]$} \\
\hline & Glycerol & $\mathrm{ChCl}$ & $1: 1$ & 1.16 & {$[26]$} \\
\hline & Glycerol & $\mathrm{ChCl}$ & $1: 2$ & 1.18 & {$[21,41]$} \\
\hline & Glycerol & $\mathrm{ChCl}$ & $1: 2$ & 1.20 & {$[41]$} \\
\hline & Glycerol & $\begin{array}{l}N, N \text {-Diethylethanolammonium } \\
\text { chloride }\end{array}$ & $1: 2$ & 1.17 & {$[26]$} \\
\hline & Glycerol & $\begin{array}{l}N, N \text {-Diethylethanolammonium } \\
\text { chloride }\end{array}$ & $1: 3$ & 1.21 & {$[26]$} \\
\hline & Glycerol & $\begin{array}{l}N, N \text {-Diethylethanolammonium } \\
\text { chloride }\end{array}$ & $1: 4$ & 1.22 & {$[26]$} \\
\hline & Glycerol & $\begin{array}{l}\text { Methyltriphenylphosphonium } \\
\text { bromide }\end{array}$ & $1: 2$ & 1.31 & [26] \\
\hline & Glycerol & $\begin{array}{l}\text { Methyltriphenylphosphonium } \\
\text { bromide }\end{array}$ & $1: 3$ & 1.30 & {$[26]$} \\
\hline & Glycerol & $\begin{array}{l}\text { Methyltriphenylphosphonium } \\
\text { bromide }\end{array}$ & $1: 4$ & 1.30 & {$[26]$} \\
\hline & Ethylene glycol & $\mathrm{ChCl}$ & $1: 2$ & 1.12 & {$[26,41]$} \\
\hline & Ethylene glycol & $\mathrm{ChCl}$ & $1: 3$ & 1.12 & {$[26,41]$} \\
\hline & Ethylene glycol & $\begin{array}{l}\text { Methyltriphenylphosphonium } \\
\text { bromide }\end{array}$ & $1: 3$ & 1.25 & {$[26]$} \\
\hline & Ethylene glycol & $\begin{array}{l}\text { Methyltriphenylphosphonium } \\
\text { bromide }\end{array}$ & $1: 4$ & 1.23 & {$[26]$} \\
\hline & Ethylene glycol & $\begin{array}{l}\text { Methyltriphenylphosphonium } \\
\text { bromide }\end{array}$ & $1: 6$ & 1.22 & {$[26]$} \\
\hline
\end{tabular}


Table 1.3 (Continued)

\begin{tabular}{|c|c|c|c|c|c|}
\hline Types & HBD & Salt & $\begin{array}{l}\text { Salt/ } \\
\text { HBD } \\
\text { molar } \\
\text { ratio }\end{array}$ & $\begin{array}{l}\rho \\
\left(\mathrm{g} / \mathrm{cm}^{3}\right)\end{array}$ & References \\
\hline & Ethylene glycol & $\begin{array}{l}N, N \text {-Diethylethanolammonium } \\
\text { chloride }\end{array}$ & $1: 2$ & 1.10 & [26] \\
\hline & Ethylene glycol & $\begin{array}{l}\mathrm{N}, \mathrm{N} \text {-Diethylethanolammonium } \\
\text { chloride }\end{array}$ & $1: 3$ & 1.10 & [26] \\
\hline & Ethylene glycol & $\begin{array}{l}N, N \text {-Diethylethanolammonium } \\
\text { chloride }\end{array}$ & $1: 4$ & 1.10 & [26] \\
\hline & Oxalic acid & $\mathrm{ChCl}$ & $1: 1$ & 1.259 & [37] \\
\hline & Glycolic acid & $\mathrm{ChCl}$ & $1: 1$ & 1.195 & [37] \\
\hline & Malonic acid & $\mathrm{ChCl}$ & $1: 1$ & 1.231 & [37] \\
\hline & Glutaric acid & $\mathrm{ChCl}$ & $1: 1$ & 1.188 & [37] \\
\hline & Levulinic acid & $\mathrm{ChCl}$ & $1: 2$ & 1.138 & [37] \\
\hline & $o$-Cresol & $\mathrm{ChCl}$ & $1: 3$ & 1.07 & [31] \\
\hline & Phenol & $\mathrm{ChCl}$ & $1: 3$ & 1.092 & {$[31]$} \\
\hline \multirow[t]{4}{*}{ IV } & Urea & $\mathrm{ZnCl}_{2}$ & $1: 3.5$ & 1.63 & [11] \\
\hline & Acetamide & $\mathrm{ZnCl}_{2}$ & $1: 4$ & 1.36 & [11] \\
\hline & Ethylene glycol & $\mathrm{ZnCl}_{2}$ & $1: 4$ & 1.45 & [11] \\
\hline & Hexanediol & $\mathrm{ZnCl}_{2}$ & $1: 3$ & 1.38 & [11] \\
\hline
\end{tabular}

For the DESs composed with $\mathrm{ChCl}$ and glycerol, the viscosity decreases with increase in the $\mathrm{ChCl} /$ glycerol molar ratio. For example, at $20^{\circ} \mathrm{C}$, viscosities of $\mathrm{ChCl}$-glycerol mixtures with a molar ratio of $1: 4,1: 3$, and $1: 2$ were 503,450 , and $376 \mathrm{cP}$, respectively, at $20^{\circ} \mathrm{C}$. Glycerol has an important intermolecular hydrogen bond network and the decrease in viscosity with increase of the $\mathrm{ChCl}$ / glycerol molar ratio was attributed to the partial rupture of this hydrogen bond network [21]. A similar trend was observed with $\mathrm{ChCl} / 1,4$-butanediol mixtures. Notably in the case of $\mathrm{ChCl} /$ ethylene glycol combination, no change in the viscosity was observed between a salt/HBD molar ratio of $1: 3$ and one of $1: 4$ (19cP at $20^{\circ} \mathrm{C}$ ). As a general summary, the high viscosity of DESs is often attributed to the presence of an extensive hydrogen bond interaction between components, leading to a lower mobility of free species within the DES. The high viscosity of DESs is also due to (i) the electrostatic or van der Waals interactions, (ii) the large ion size and very small void volume of most DESs, and (iii) the free volume. As was shown by Abbott et al. $[18,41]$, the hole theory shows that viscosity is correlated with the availability of holes in the fluid that allow suitable ionic motion, and thus, the viscosity is mainly controlled by volumetric factors in spite of the strong intermolecular interactions developed in these systems. Therefore, although ion-HBD interactions play an important role in the DES viscosity, steric effects should be taken into account. Based on the hole theory, DESs with 


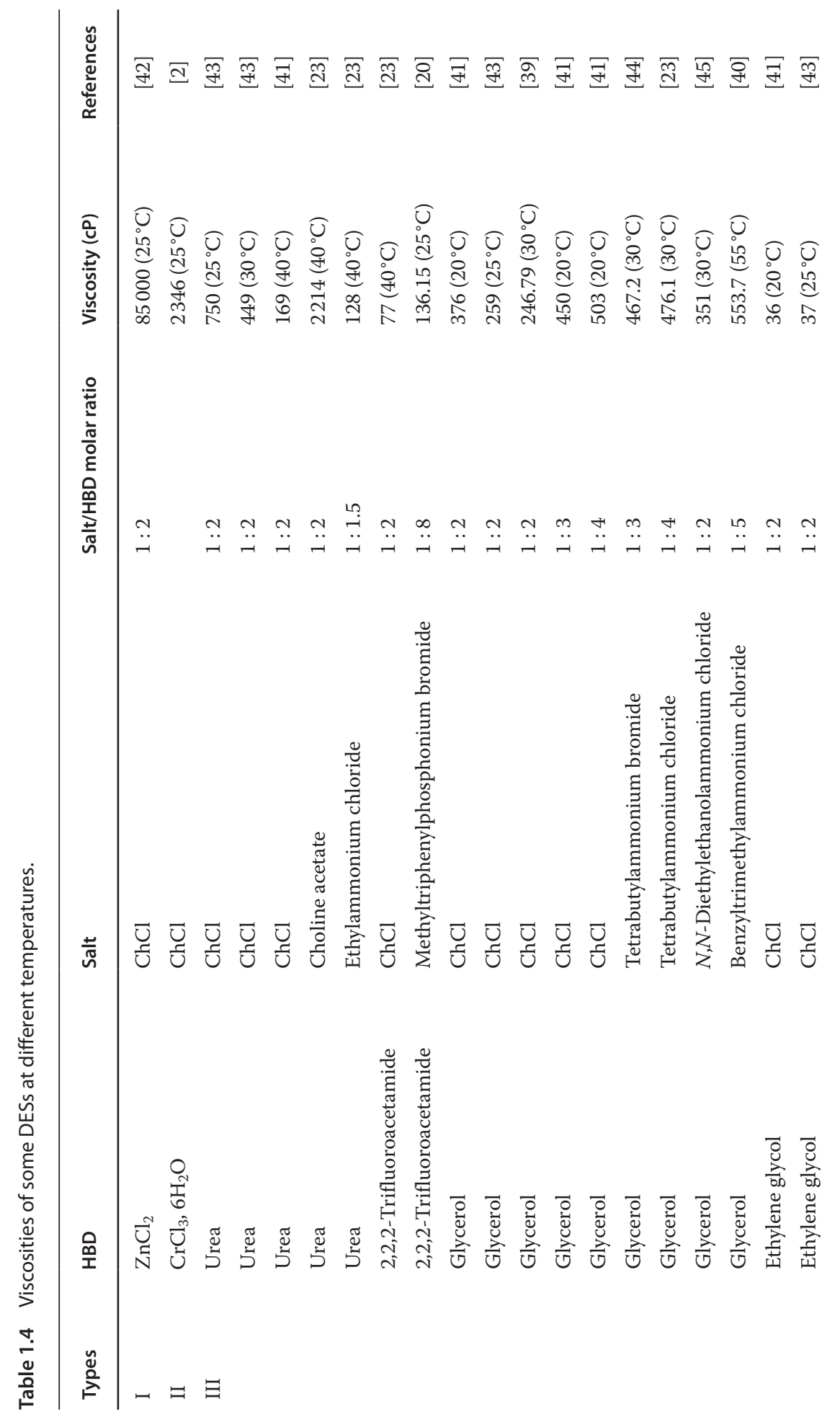




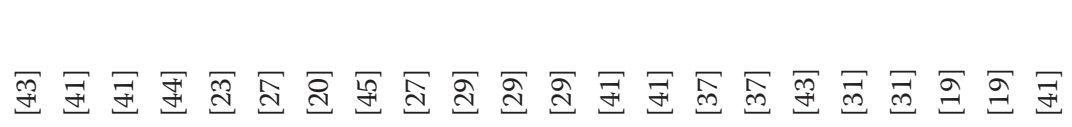

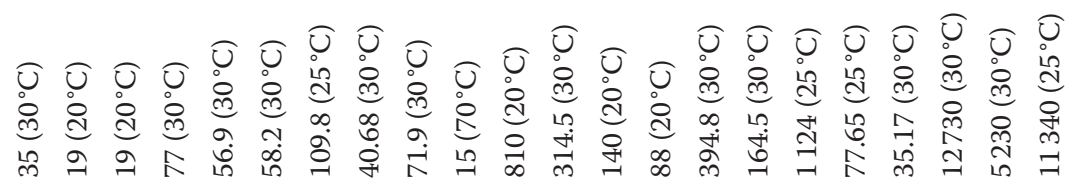

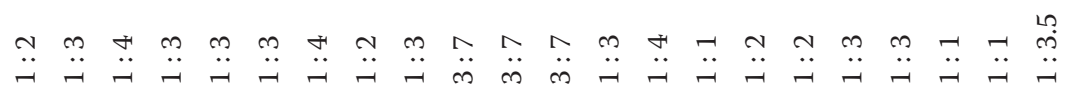

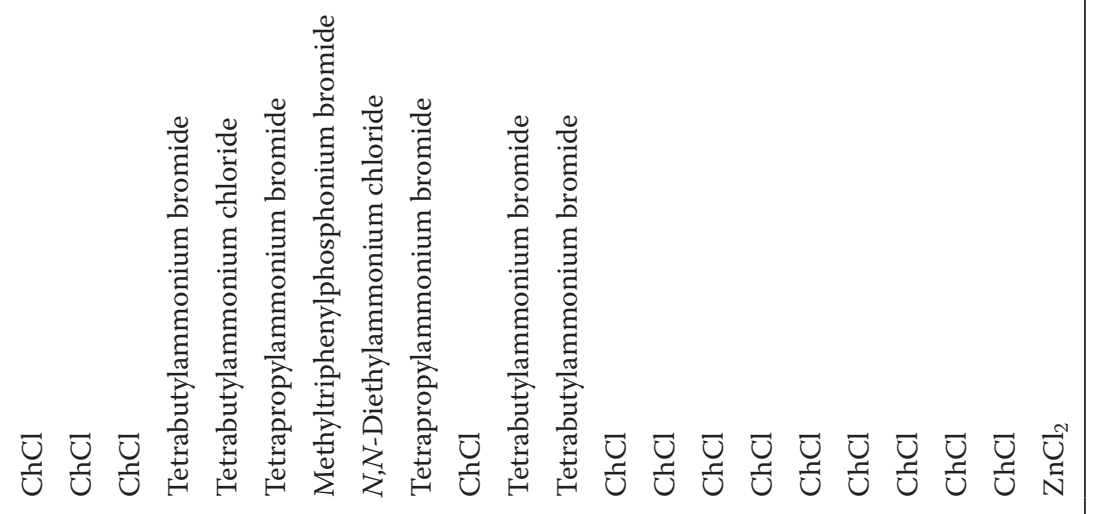

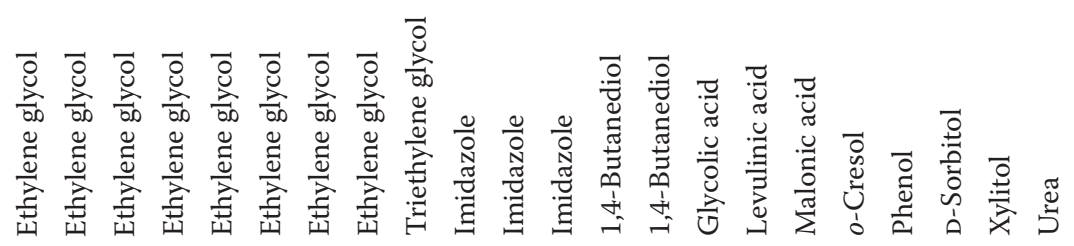
$\geq$ 
low viscosities using small cations or fluorinated HBDs can be obtained [18]. As for other solvents, the viscosity changes with temperature; increase of the temperature leads to a decrease of the viscosity. For example, the viscosity of a mixture of $\mathrm{ChCl} /$ urea decreased from 750 to $169 \mathrm{cP}$ with an increase of the temperature from 25 to $40^{\circ} \mathrm{C}$.

It can be pointed out that there exist many differences in the literature in the viscosity for the same DES probably due to the (i) experimental method, (ii) DES synthesis, and (iii) impurities such as water. For example, depending on the preparation method of DESs (traditional heating and stirring method or grinding approach), 6.5\% difference between viscosity data for DES was observed [37]. Another important parameter is the water content that can affect the viscosity of DESs since many types of DES are highly hygroscopic. Therefore, the water content should be provided to compare data reported in the literature, which is not common. Hence, Yadav and Pandey [39] demonstrated that the viscosity of $\mathrm{ChCl} /$ urea (1 : 2 molar ratio) decreases from $527.3 \mathrm{cP}$ for pure DES to $200.6 \mathrm{cP}$ for DES with 0.1 water mole fraction. Highly viscous $\mathrm{DESs}$ such as $\mathrm{ChCl}$ and oxalic acid (1:1 molar ratio) are capable of capturing water from atmospheric moisture up to $19.40 \mathrm{wt} \%$, which decreases the viscosity from 53.63 to $44.49 \mathrm{cP}$. These results highlight that it is possible to decrease the viscosity of highly viscous DESs by adding controlled amounts of water. Nevertheless, this should be done with caution since it may affect the properties of DESs.

It is worthwhile mentioning that there is a lack of development of predictive viscosity models for DESs using approaches such as quantitative structure-activity relationship (QSAR) or group contribution methods, and therefore, systematic experimental and theoretical studies should be carried out.

\subsubsection{Ionic Conductivity}

The ionic conductivities of DESs are relatively low and are correlated to the viscosity of DESs. Thus, most of the DESs present an ionic conductivity lower than $1 \mathrm{mS} / \mathrm{cm}$ at room temperature [6]. Only the DESs composed of ethylene glycol or imidazole and $\mathrm{ChCl}$ show high ionic conductivities $\left(7.61 \mathrm{mS} / \mathrm{cm}\right.$ at $20^{\circ} \mathrm{C}$ and $12 \mathrm{mS} / \mathrm{cm}$ at $60^{\circ} \mathrm{C}$ respectively) owing to their low viscosities. The relationship between viscosity and conductivity can be determined by plotting molar conductivity and fluidity (inverse of the viscosity) on a log-log scale (Walden plot). This curve is compared with the ideal line obtained for $0.01 \mathrm{M} \mathrm{KCl}$ aqueous solution, which has a slope equal to 1 and goes through the origin of coordinates. Based on this, it was found that low-viscosity DESs (e.g. those with ethylene glycol) show lower ionic conductivities, whereas very viscous ones lie closer to the ideal line. Ionic conductivities increase with increase of temperature as shown in Table 1.5. The effect of temperature on conductivity is commonly described according to Arrhenius-type behavior [1, 20, 21, 23, 27, 46].

Ionic conductivity can be tuned also by varying the organic salt/HBD molar ratio [1].

The prediction of DES ionic conductivity was studied by Abbott et al. [41] and they have demonstrated that the availability of suitable holes and the type and strength of ion-HBD interactions determine the ion mobility and thus 


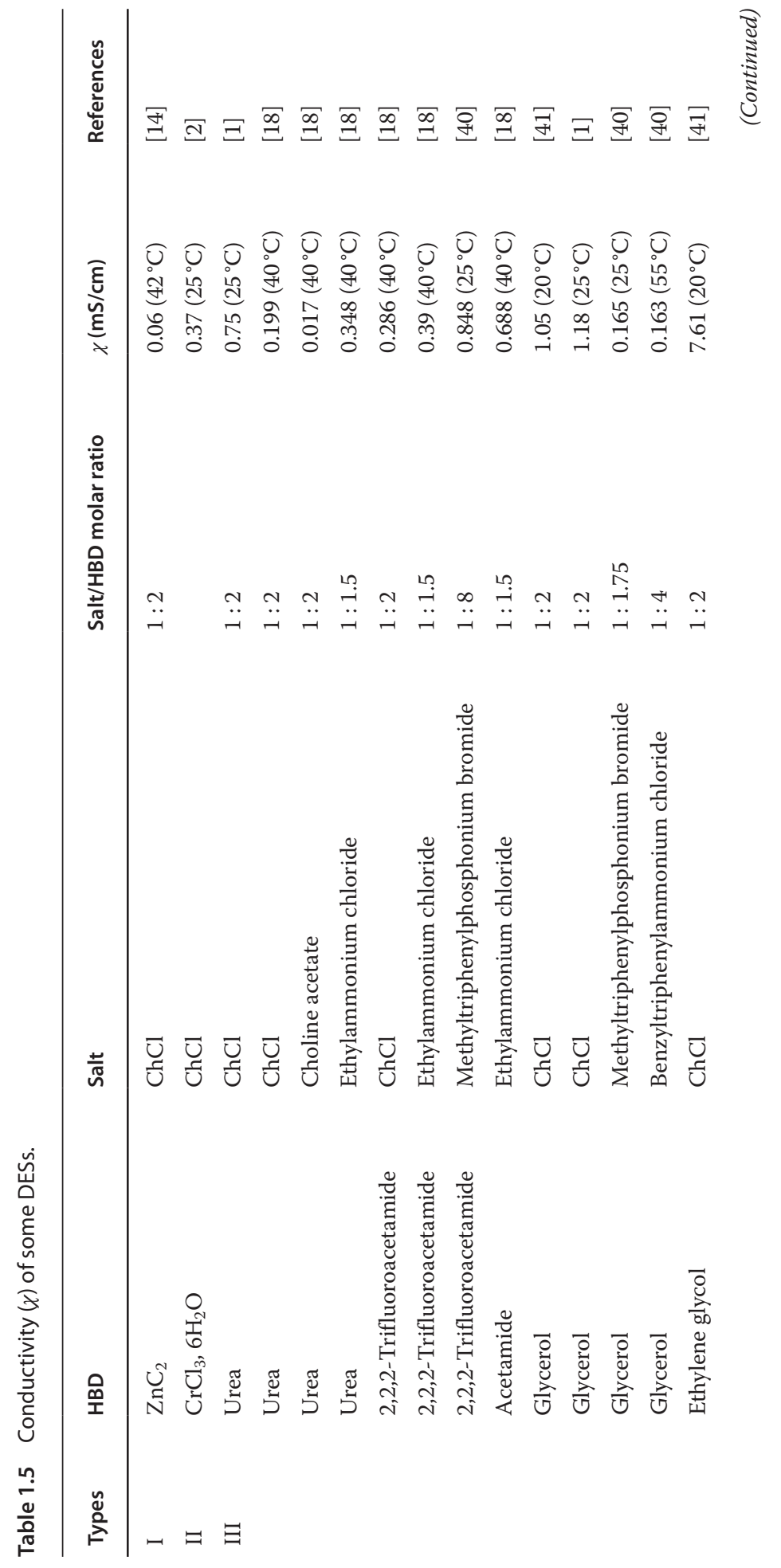




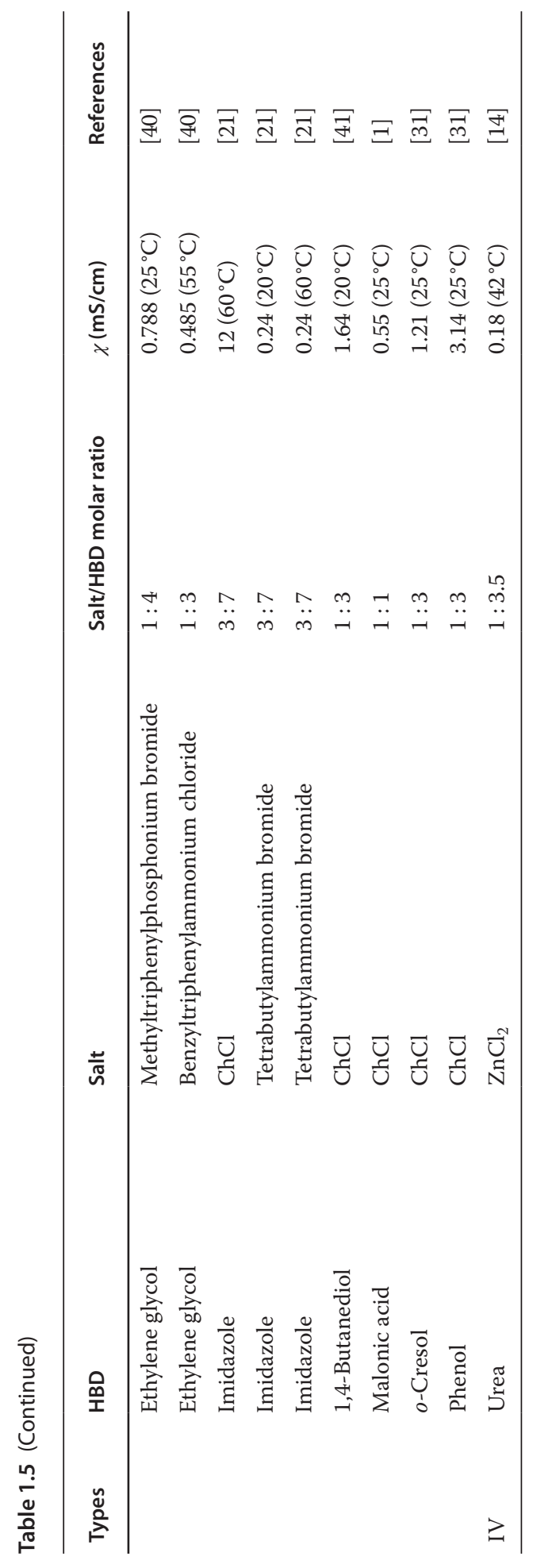


conductivity. Moreover, the variation of the conductivity with salt concentration is dependent on both the type of salt and the HBD. This leads to systems in which the conductivity decreases with increasing salt concentration or systems in which the conductivity-salt concentration trend evolves through a maximum.

\subsubsection{Polarity}

Although DESs are considered as environmentally friendly alternative solvents to common volatile organic solvents, information on the polarity of DESs is scarcely reported in the literature. However, Abbott et al. [21] characterized the solvent polarity of a mixture of $\mathrm{ChCl}$ and glycerol at different salt/HBD molar ratios $(1: 1,1: 1: 5,1: 2$, and $1: 3)$ using Reichardt's dye scale (ET(30) parameter) [47] and the Kamlet-Taft scale ( $\pi^{*}, \alpha$, and $\beta$ parameters) [48]. $\mathrm{ChCl}$ and glycerol DESs are polar fluids with polarities in the range of those for primary and secondary alkylammonium ionic liquids [49].

Other authors Pandey et al. [50] carried out a large experimental study on ChClbased DESs using several solvatochromic probes. They used betaine dye 33 to calculate the $\mathrm{ET}(30)$ parameter. They confirmed that $\mathrm{ChCl} /$ urea $(1: 2), \mathrm{ChCl}$ / glycerol $(1: 2)$, and $\mathrm{ChCl} /$ ethylene glycol are highly polar fluids and their polarity is even higher than those of short-chain alcohols and most common ionic liquids. Glycerol DESs have the largest ET(30) values followed by ethylene glycol and urea DESs. This was ascribed to the number of hydroxyl groups in HBDs.

\subsubsection{Surface Tension}

The surface tension of DES is remarkably high and is strongly dependent on the strength of intermolecular forces between the HBDs and the corresponding salt. As shown in Table 1.6, ChCl/ethylene glycol and tetraalkylammonium-based DESs possess a high surface tension. Moreover, $\mathrm{ChCl} /$ malonic acid and $\mathrm{ChCl}$ / fructose or glucose present a high surface tension $(65.7,74.01$, and $71.7 \mathrm{mN} / \mathrm{m}$ respectively) due to large hydrogen bonding. The nature of the cation impacts also the surface tension. A cation containing a hydroxyl group leads to a DES with high surface tension as is the case with $\mathrm{ChCl} /$ glycerol for instance $(56 \mathrm{mN} / \mathrm{m})$. In the case of tetraalkylammonium-based DES, the increase in the chain length leads to an increase in the surface tension. For instance, tetrapropylammonium bromide/glycerol DES has a surface tension of $46 \mathrm{mN} / \mathrm{m}$ whereas the surface tension of tetrabutylammonium chloride/glycerol is $52.7 \mathrm{mN} / \mathrm{m}$. The temperature and the salt molar fraction have an impact on the surface tension. In all the studied DESs, the surface tension increases with a decrease in the temperature [21, $23,27,28,38]$ and the salt molar fraction due to the weakening of the HBD hydrogen bonding [21]. Some data were provided by Abbott et al. on the surface tension of $\mathrm{ChCl}$-based and $\mathrm{ZnCl}_{2}$-based DESs [1]. They have shown that all these values were higher than the surface tensions of most of the molecular solvents and comparable to those of imidazolium-based ILs and high-temperature molten salts, e.g. 1-butyl-3-methylimidazolium tetrafluoroborate ([BMIM]BF4, $38.4 \mathrm{mN} / \mathrm{m}$ at $\left.63^{\circ} \mathrm{C}\right)$ and $\mathrm{KBr}\left(77.3 \mathrm{mN} / \mathrm{m}\right.$ at $\left.900^{\circ} \mathrm{C}\right)$. They have also demonstrated that there is a relationship between the viscosity and the surface tension. 
Table 1.6 Surface tension $(\gamma)$ of some DESs.

\begin{tabular}{|c|c|c|c|c|}
\hline HBD & Salt & $\begin{array}{l}\text { Salt/ } \\
\text { HBD } \\
\text { molar } \\
\text { ratio }\end{array}$ & $\gamma(\mathrm{mN} / \mathrm{m})$ & References \\
\hline Urea & $\mathrm{ChCl}$ & $1: 2$ & $52\left(25^{\circ} \mathrm{C}\right)$ & {$[43]$} \\
\hline $\begin{array}{l}\text { 2,2,2- } \\
\text { Trifluoroacetamide }\end{array}$ & $\begin{array}{l}N, N \text {-Diethylethanolammonium } \\
\text { chloride }\end{array}$ & $1: 2$ & $40.27\left(25^{\circ} \mathrm{C}\right)$ & {$[28]$} \\
\hline Glycerol & $\mathrm{ChCl}$ & $1: 2$ & $56\left(25^{\circ} \mathrm{C}\right)$ & {$[43]$} \\
\hline Glycerol & $\mathrm{ChCl}$ & $1: 3$ & $50.8\left(20^{\circ} \mathrm{C}\right)$ & {$[43]$} \\
\hline Glycerol & Tetrapropylammonium bromide & $1: 3$ & $46\left(30^{\circ} \mathrm{C}\right)$ & {$[23]$} \\
\hline Glycerol & Tetrabutylammonium chloride & $1: 3$ & $52.7\left(30^{\circ} \mathrm{C}\right)$ & [27] \\
\hline Glycerol & $\begin{array}{l}N, N \text {-Diethylethanolammonium } \\
\text { chloride }\end{array}$ & $1: 4$ & $59.35\left(25^{\circ} \mathrm{C}\right)$ & {$[28]$} \\
\hline Glycerol & $\begin{array}{l}\text { Methyltriphenylphosphonium } \\
\text { bromide }\end{array}$ & $1: 3$ & $58.94\left(25^{\circ} \mathrm{C}\right)$ & {$[28]$} \\
\hline Ethylene glycol & $\mathrm{ChCl}$ & $1: 2$ & $48\left(25^{\circ} \mathrm{C}\right)$ & [43] \\
\hline Ethylene glycol & $\mathrm{ChCl}$ & $1: 3$ & $45.4\left(20^{\circ} \mathrm{C}\right)$ & {$[41]$} \\
\hline Ethylene glycol & Tetrapropylammonium bromide & $1: 3$ & $40.1\left(30^{\circ} \mathrm{C}\right)$ & {$[23]$} \\
\hline Ethylene glycol & Tetrabutylammonium chloride & $1: 3$ & $46.2\left(30^{\circ} \mathrm{C}\right)$ & {$[27]$} \\
\hline Ethylene glycol & $\begin{array}{l}\text { Methyltriphenylphosphonium } \\
\text { bromide }\end{array}$ & $1: 4$ & $51.29\left(25^{\circ} \mathrm{C}\right)$ & {$[28]$} \\
\hline Ethylene glycol & $\begin{array}{l}N, N \text {-Diethylethanolammonium } \\
\text { chloride }\end{array}$ & $1: 3$ & $47.51\left(25^{\circ} \mathrm{C}\right)$ & {$[28]$} \\
\hline Triethylene glycol & $\begin{array}{l}\text { Methyltriphenylphosphonium } \\
\text { bromide }\end{array}$ & $1: 5$ & $49.85\left(25^{\circ} \mathrm{C}\right)$ & {$[28]$} \\
\hline Triethylene glycol & Tetrabutylammonium chloride & $3: 1$ & $46.2\left(30^{\circ} \mathrm{C}\right)$ & [27] \\
\hline Triethylene glycol & Tetrapropylammonium bromide & $1: 3$ & $39.3\left(30^{\circ} \mathrm{C}\right)$ & {$[23]$} \\
\hline 1,4-Butanediol & $\mathrm{ChCl}$ & $1: 3$ & $47.17\left(25^{\circ} \mathrm{C}\right)$ & {$[28]$} \\
\hline Malonic acid & $\mathrm{ChCl}$ & $1: 1$ & $65.7\left(25^{\circ} \mathrm{C}\right)$ & [43] \\
\hline Phenylacetic acid & $\mathrm{ChCl}$ & $1: 1$ & $41.86\left(25^{\circ} \mathrm{C}\right)$ & {$[1]$} \\
\hline D-Fructose & $\mathrm{ChCl}$ & $2: 1$ & $74.01\left(25^{\circ} \mathrm{C}\right)$ & {$[38]$} \\
\hline D-Glucose & $\mathrm{ChCl}$ & $2: 1$ & $71.7\left(25^{\circ} \mathrm{C}\right)$ & [33] \\
\hline Urea & $\mathrm{ZnCl}_{2}$ & $1: 3.5$ & $72\left(25^{\circ} \mathrm{C}\right)$ & {$[1]$} \\
\hline Acetamide & $\mathrm{ZnCl}_{2}$ & $1: 4$ & $53\left(25^{\circ} \mathrm{C}\right)$ & [1] \\
\hline Ethylene glycol & $\mathrm{ZnCl}_{2}$ & $1: 4$ & $56.9\left(25^{\circ} \mathrm{C}\right)$ & {$[1]$} \\
\hline 1,6-Hexanediol & $\mathrm{ZnCl}_{2}$ & $1: 3$ & $19\left(25^{\circ} \mathrm{C}\right)$ & {$[1]$} \\
\hline
\end{tabular}

Thus, the surface tension of the $\mathrm{ChCl} /$ glycerol DES decreases with increase in $\mathrm{ChCl}$ concentration, due to the disturbance of the hydrogen bond network of glycerol, as previously discussed for viscosity. Moreover, the surface tensions of various $\mathrm{ChCl} /$ glycerol DESs showed a linear correlation with temperature [21]. 


\subsection{Summary and Conclusions}

DESs are easily prepared and their properties are directly correlated to the nature of the HBD and salt interaction and to the temperature. The method of DES synthesis has an impact on the DES thermophysical properties and to a larger extent on viscosity than on density. It can be pointed out that there are differences among the data reported in the literature due to impurities such as the water content of each component of the DES and the preparation method. However, the physicochemical properties of DESs can be tuned by changing the nature of the salt and the HBD. DESs offer many advantages such as their easy preparation, which is $100 \%$ atom economic, and their low price due to the salt and HBD used for their synthesis. Moreover, they are quite nontoxic, especially ChCl-based DESs. All these advantages open alternative routes for the emergence of DESs in a wide range of industrial applications. It should also be noted that although components of DESs are potentially reactive chemicals, their autoassociation by a hydrogen bond limits their reactivity, allowing their use in many fields of research as reported in the following chapters.

\section{References}

1 (a) Abbott, A.P., Capper, G., Davies, D.L. et al. (2001). Chem. Commun.: 20102011. (b) Abbott, A.P., Capper, G., Davies, D.L. et al. (2003). Chem. Commun.: 70-71. (c) Abbott, A.P., Boothby, D., Capper, G. et al. (2004). J. Am. Chem. Soc. 126: 9142-9147.

2 Smith, E.L., Abbott, A.P., and Ryder, K.S. (2014). Chem. Rev. 114: 11060-11082.

3 Pincock, R.E. (1969). Acc. Chem. Res. 2: 97-103.

4 Rus, C. and Konig, B. (2012). Green Chem. 14: 2969-2982.

5 Francisco, M., van den Bruinhorst, A., and Kroon, M.C. (2013). Angew. Chem. Int. Ed. 52: 3074-3085.

6 Zhang, Q.H., De Oliveira Vigier, K., Royer, S., and Jérôme, F. (2012). Chem. Soc. Rev. 41: 7108-7146.

7 Deetlefs, M. and Seddon, K.R. (2010). Green Chem. 12: 17-30.

8 Gorke, J.T., Srienc, F., and Kazlauskas, R.J. (2010). Ionic Liquid Applications: Pharmaceuticals, Therapeutics, and Biotechnology, ACS symposium series, 69-180. Oxford University Press.

9 Morrison, H.G., Sun, C.C., and Neervannan, S. (2009). Int. J. Pharm. 378: $136-139$.

10 Singh, B.S., Lobo, H.R., and Shankarling, G.S. (2012). Catal. Commun. 24: 70-74.

11 Abbott, A.P., Barron, J.C., Ryder, K.S., and Wilson, D. (2007). Chem. Eur. J. 13: 6495-6501.

12 Abbott, A.P., Al-Barzinjy, A.A., Abbott, P.D. et al. (2014). Phys. Chem. Chem. Phys. 16: 9047-9055.

13 Alonso, D.A., Baeza, A., Chinchilla, R. et al. (2016). Eur. J. Org. Chem.: 612-632. 
14 Abbott, A.P., Capper, G., Davies, D.L., and Rasheed, R. (2004). Inorg. Chem. 43: 3447-3452.

15 Liu, Y.T., Chen, Y.A., and Xing, Y.J. (2014). Chin. Chem. Lett. 25: 104-106.

16 Wang, H., Jing, Y., Wang, X. et al. (2011). J. Mol. Liq. 163: 77-82.

17 Zhao, H., Baker, G.A., and Holmes, S. (2011). Org. Biomol. Chem. 9: 1908-1916.

18 Abbott, A.P., Capper, G., and Gray, S. (2006). ChemPhysChem 7: 803-806.

19 Shabaz, K., Mjalli, F.S., Hashim, M.A., and Al-Nashef, I.M. (2010). J. Appl. Sci. 10: 3349-3354.

20 Kareem, M.A., Mjalli, F.S., Hashim, M.A., and Alnashef, I.M. (2010). J. Chem. Eng. Data 55: 4632-4637.

21 Abbott, A.P., Harris, R.C., Ryder, K.S. et al. (2011). Green Chem. 13: 82-90.

22 Hayyan, M., Mjalli, F.S., Hashim, M.A., and AlNashef, I.M. (2010). Fuel Process. Technol. 91: 116-120.

23 Mjalli, F.S., Naser, J., Jibril, B. et al. (2014). J. Chem. Eng. Data 59: 2242-2251.

24 Petkovic, M., Seddon, K.R., Rebelo, L.P.N., and Silva-Pereira, C. (2011). Chem. Soc. Rev. 40: 1383-1403.

25 Shahbaz, K., Mjalli, F.S., Hashim, M.A., and AlNashef, I.M. (2011). Energy Fuels 25: 2671-2678.

26 Shahbaz, K., Baroutian, S., Mjalli, F.S. et al. (2012). Thermochim. Acta 527: 59-66.

27 Jibril, B., Mjalli, F., Naser, J., and Gano, Z. (2014). J. Mol. Liq. 199: 462-469.

28 Ventura, S.P.M., Silva, F., Goncalves, A.M.M. et al. (2014). Ecotoxicol. Environ. Saf. 102: 48-54.

29 Hou, Y., Gu, Y., Zhang, S. et al. (2008). J. Mol. Liq. 143: 154-159.

30 Maugeri, Z. and Domínguez de María, P. (2012). RSC Adv. 2: 421-425.

31 Guo, W., Hou, Y., Ren, S. et al. (2013). J. Chem. Eng. Data 58: 866-872.

32 Hayyan, A., Mjalli, F.S., AlNashef, I.M. et al. (2012). Thermochim. Acta 541: $70-75$.

33 Hayyan, A., Mjalli, F.S., AlNashef, I.M. et al. (2013). J. Mol. Liq. 178: 137-141.

34 Carriazo, D., Gutiérrez, M.C., Ferrer, M.L., and del Monte, F. (2010). Chem. Mater. 22: 6146-6152.

35 Sitze, M.S., Schreiter, E.R., Patterson, E.V., and Freeman, R.G. (2001). Inorg. Chem. 40: 2298-2304.

36 Scheffler, T.B. and Thomson, M. (1990). Seventh International Conference on Molten Salts, 281-289. Montreal: The Electrochemical Society.

37 (a) Smith, R. and Tanford, C. (1973). Proc. Natl. Acad. Sci. U.S.A. 70: 289-293.

(b) Florindo, C., Oliveira, F.S., Rebelo, L.P.N. et al. (2014). ACS Sustainable Chem. Eng. 2: 2416-2425.

38 Mjalli, F.S., Vakili-Nezhaad, G., Shahbaz, K., and AlNashef, I.M. (2014). Thermochim. Acta 575: 40-44.

39 Yadav, A., Trivedi, S., Rai, R., and Pandey, S. (2014). Fluid Phase Equilib. 367: 135-142.

40 Shahbaz, K., Mjalli, F.S., Hashim, M.A., and AlNashef, I.M. (2012). Fluid Phase Equilib. 319: 48-54.

41 Abbott, A.P., Harris, R.C., and Ryder, K.S. (2007). J. Phys. Chem. B 111: $4910-4913$. 
42 Borse, B.N., Shukla, S.R., Sonawane, Y.A., and Shankarling, G.S. (2013). Synth. Commun. 43: 865-876.

43 D’Agostino, C., Harris, R.C., Abbott, A.P. et al. (2011). Phys. Chem. Chem. Phys. 13: 21383-21391.

44 Yusof, R., Abdulmalek, E., Sirat, K. et al. (2014). Molecules 19: 8011-8026.

45 Siongco, K., Leron, R.B., and Li, M.H. (2013). J. Chem. Thermodyn. 65: 65-72.

46 Bahadori, L., Chakrabarti, M.H., Mjalli, F.S. et al. (2013). Electrochim. Acta 113: 205-211.

47 Reichardt, C. (1994). Chem. Rev. 94: 2319-2358.

48 Kamlet, M.J. and Taft, R.W. (1976). J. Am. Chem. Soc. 98: 377-383.

49 Reichardt, C. (2005). Green Chem. 7: 339-351.

50 Pandey, A., Rai, R., Pal, M., and Pandey, S. (2014). Phys. Chem. Chem. Phys. 16: 1559-1568. 
